\title{
Front Matter: Volume 7504
}

, "Front Matter: Volume 7504," Proc. SPIE 7504, Laser-Induced Damage in Optical Materials: 2009, 750401 (19 January 2010); doi: 10.1117/12.856139 


\title{
LASER-INDUCED DAMAGE IN OPTICAL MATERIALS: 2009
}

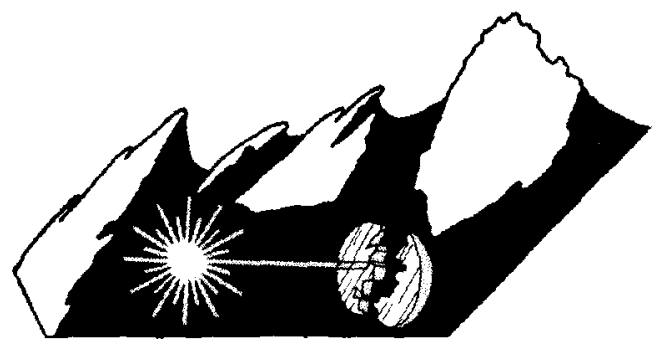

\section{1-23 September 2009 \\ Boulder, Colorado}

\section{Editors}

Gregory J. Exarhos, Vitaly E. Gruzdev, Detlev Ristau, M. J. Soileau, Christopher J. Stolz

$$
\begin{gathered}
\text { Organized by } \\
\text { SPIE }
\end{gathered}
$$

\section{Cosponsored by}

\section{Lawrence Livermore National Laboratory (United States)}

Laser Zentrum Hannover e.V. (Germany)

Office of Naval Research (United States)

Pacific Northwest National Lab. (United States)

Spica Technologies, Inc. (United States)

\section{Cooperating Organizations}

National Institute of Standards and Technology (United States)

Electromagnetic Remote Sensing Defence Technology Centre (United Kingdom)

CREOL \& FPCE, College of Optics and Photonics, University of Central Florida (United States)

$$
\text { Founding Organizers }
$$

Arthur H. Guenther and Alexander J. Glass

\section{Published by}

SPIE

\section{Proceedings of SPIE Volume 7504}

\author{
Proceedings of SPIE, 0277-786X, v. 7504
}


The papers included in this volume were part of the technical conference cited on the cover and title page. Papers were selected and subject to review by the editors and conference program committee. Some conference presentations may not be available for publication. The papers published in these proceedings reflect the work and thoughts of the authors and are published herein as submitted. The publisher is not responsible for the validity of the information or for any outcomes resulting from reliance thereon.

Please use the following format to cite material from this book:

Author(s), "Title of Paper," in Laser-Induced Damage in OpticalMaterials: 2009, edited by Gregory J. Exarhos, Vitaly E. Gruzdev, Detlev Ristau, M. J. Soileau, Christopher J. Stolz, Proceedings of SPIE Vol. 7504 (SPIE, Bellingham, WA, 2009) Article CID Number.

ISSN 0277-786X

ISBN 9780819478825

Published by

SPIE

P.O. Box 10, Bellingham, Washington 98227-0010 USA

Telephone +1 3606763290 (Pacific Time) · Fax +1 3606471445

SPIE.org

Copyright (C) 2009, Society of Photo-Optical Instrumentation Engineers

Copying of material in this book for internal or personal use, or for the internal or personal use of specific clients, beyond the fair use provisions granted by the U.S. Copyright Law is authorized by SPIE subject to payment of copying fees. The Transactional Reporting Service base fee for this volume is $\$ 18.00$ per article (or portion thereof), which should be paid directly to the Copyright Clearance Center (CCC), 222 Rosewood Drive, Danvers, MA 01923. Payment may also be made electronically through CCC Online at copyright.com. Other copying for republication, resale, advertising or promotion, or any form of systematic or multiple reproduction of any material in this book is prohibited except with permission in writing from the publisher. The CCC fee code is $0277-786 \mathrm{X} / 09 / \$ 18.00$.

Printed in the United States of America.

Publication of record for individual papers is online in the SPIE Digital Library.

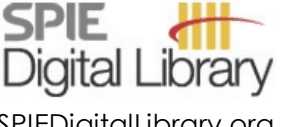

SPIEDigitalLibrary.org

Paper Numbering: Proceedings of SPIE follow an e-First publication model, with papers published first online and then in print and on CD-ROM. Papers are published as they are submitted and meet publication criteria. A unique, consistent, permanent citation identifier (CID) number is assigned to each article at the time of the first publication. Utilization of CIDs allows articles to be fully citable as soon they are published online, and connects the same identifier to all online, print, and electronic versions of the publication. SPIE uses a six-digit CID article numbering system in which:

- The first four digits correspond to the SPIE volume number.

- The last two digits indicate publication order within the volume using a Base 36 numbering system employing both numerals and letters. These two-number sets start with $00,01,02,03,04,05,06,07,08,09,0 \mathrm{~A}, 0 \mathrm{~B} \ldots 0 \mathrm{Z}$, followed by 10-1Z, 20-2Z, etc.

The CID number appears on each page of the manuscript. The complete citation is used on the first page, and an abbreviated version on subsequent pages. Numbers in the index correspond to the last two digits of the six-digit CID number. 


\section{Contents}

ix

xi Symposium Welcome

V. Guzdev

xiii Summary of Meeting

C. J. Stolz

\section{THIN FILMS}

750402 The effect of nitrogen doping on the multiple-pulse subpicosecond dielectric breakdown of hafnia films [7504-10]

D. N. Nguyen, L. A. Emmert, W. Rudolph, The Univ. of New Mexico (United States); D. Patel, E. Krous, C. S. Menoni, Colorado State Univ. (United States)

750403 Studies of femtosecond laser-induced damage of $\mathrm{HfO}_{2}$ thin film in atmospheric and vacuum environments [7504-09]

D. N. Nguyen, L. A. Emmert, W. Rudolph, The Univ. of New Mexico (United States); D. Patel, E. Krous, C. S. Menoni, Colorado State Univ. (United States); M. Shinn, Thomas Jefferson National Accelerator Facility (United States)

750404 Surface damage of thin AlN films with increased oxygen content by nanosecond and femtosecond laser pulses [7504-11]

V. Gruzdev, Univ. of Missouri, Columbia (United States); I. Salakhutdinov, Queens College, CUNY (United States); J. K. Chen, Univ. of Missouri, Columbia (United States); Y. Danylyuk, E. McCullen, G. Auner, Wayne State Univ. (United States)

750405 Laser damage resistant pits in dielectric coatings created by femtosecond laser machining [7504-12] J. Wolfe, R. Qiu, C. Stolz, Lawrence Livermore National Lab. (United States); M. Thomas, Spica Technologies, Inc. (United States); C. Martinez, A. Ozkan, Raydiance Inc. (United States)

750406 Thermal robustness of ion beam sputtered $\mathrm{TiO}_{2} / \mathrm{SiO}_{2}, \mathrm{TiO}_{2} / \mathrm{Al}_{2} \mathrm{O}_{3}$, and $\mathrm{Al}_{2} \mathrm{O}_{3} / \mathrm{SiO}_{2}$ IR anti-reflective coatings on YAG and sapphire substrates [7504-13]

D. C. Ness, N. Traggis, O. Lyngnes, Precision Photonics Corp. (United States)

750407 Optimization of scandia thin films for high power laser coating applications [7504-15]

E. M. Krous, D. Patel, Colorado State Univ. (United States); A. Markosyan, Stanford Univ. (United States); D. N. Nguyen, L. A. Emmert, The Univ. of New Mexico (United States); P. Langston, Colorado State Univ. (United States); R. Route, M. Fejer, Stanford Univ. (United States); W. Rudolph, The Univ. of New Mexico (United States); M. Shinn, Thomas Jefferson National Accelerator Facility (United States); C. S. Menoni, Colorado State Univ. (United States)

750408 Laser conditioning of high reflectivity mirrors used in OPOs by 266 and $355 \mathrm{~nm}$ nanosecond pulses [7504-16]

A. Melninkaitis, A. Vaninas, J. Mirauskas, K. Kuršelis, O. Balachninaite, V. Sirutkaitis, Vilnius Univ. (Lithuania)

$750409 \quad 193 \mathrm{~nm}$ laser induced spectral shift in HR coated mirrors [7504-17]

B. Cho, J. E. Rudisill, E. Danielewicz, Newport Corp. (United States) 
7504 0A Design consideration for high damage threshold UV-Vis-IR mirrors [7504-02]

V. Pervak, Ludwig-Maximilians-Univ. München (Germany); M. Trubetskov, A. Tikhonravov, Lomonosov

Moscow State Univ. (Russian Federation)

7504 0B Investigation in oxide mixture coatings with adapted gradient index profiles [7504-19]

K. Starke, Cutting Edge Coatings GmbH (Germany) and Laser Zentrum Hannover e.V. (Germany); L. O. Jensen, M. Jupé, D. Ristau, Laser Zentrum Hannover e.V. (Germany); G. Abromavicius, Institute of Physics (Lithuania) and Optida Co. Ltd. (Lithuania); K. Juskevicius, R. Buzelis, Institute of Physics (Lithuania); R. Drazdys, Institute of Physics (Lithuania) and Optida Co. Ltd. (Lithuania)

7504 0C Meeting thin film design and production challenges for laser damage resistant optical coatings at the Sandia Large Optics Coating Operation [7504-20]

J. Bellum, D. Kletecka, P. Rambo, I. Smith, M. Kimmel, J. Schwarz, M. Geissel, G. Copeland, B. Atherton, Sandia National Labs. (United States); D. Smith, C. Smith, Plymouth Grating Lab Inc. (United States); C. Khripin, The Univ of New Mexico (United States)

7504 0D Influence of subsurface defects on $355 \mathrm{~nm}$ laser damage resistance of monolayer and multilayer coatings [7504-21]

G. Hu, Shanghai Institute of Optics and Fine Mechanics (China) and Graduate School of the Chinese Academy of Sciences (China); S. Shao, Shanghai Institute of Optics and Fine Mechanics (China); M. Yang, Shanghai Institute of Optics and Fine Mechanics (China) and Graduate School of the Chinese Academy of Sciences (China); J. Shao, Y. Zhao, K. Yi, Z. Fan, Shanghai Institute of Optics and Fine Mechanics (China)

$75040 \mathrm{E} \quad$ Anti-reflection coating damage threshold dependence on substrate material [7504-22] O. Lyngnes, A. Ode, D. C. Ness, Precision Photonics Corp. (United States)

$75040 \mathrm{~F} \quad$ Optical coatings with ultralow refractive index $\mathrm{SiO}_{2}$ films [7504-23]

J. Wang, Corning Inc. (United States); B. Zhou, J. Shen, G. Wu, Tongji Univ. (China)

\section{FUNDAMENTAL MECHANISMS}

7504 0G Ultrafast laser-induced modifications of energy bands of non-metal crystals (Invited Paper) [7504-27]

V. Gruzdev, Univ. of Missouri, Columbia (United States)

$7504 \mathrm{OH} \quad$ Laser-induced damage and nonlinear absorption of ultrashort laser pulses in the bulk of fused silica [7504-05]

M. Turowski, M. Jupé, L. Jensen, D. Ristau, Laser Zentrum Hannover e.V. (Germany)

7504 OI Influence of Na-related defects on DUV nonlinear absorption in $\mathrm{CaF}_{2}$ : nanosecond versus femtosecond laser pulses (Best Poster Paper Award) [7504-03]

Ch. Mühlig, H. Stafast, W. Triebel, Th. Zeuner, Ch. Karras, Institute of Photonic Technology (Germany); M. Letz, SCHOTT AG (Germany)

7504 0J A microscopic model for long-term laser damage in calcium fluoride [7504-04]

S. Rix, SCHOTT AG (Germany) and Johannes Gutenberg Univ. Mainz (Germany); U. Natura, M. Letz, SCHOTT AG (Germany); C. Felser, Johannes Gutenberg Univ. Mainz (Germany); L. Parthier, SCHOTT AG (Germany)

$75040 \mathrm{~K} \quad$ Biaxial flexural strength of optical window materials [7504-26]

C. A. Klein, C.A.K. Analytics, Inc. (United States)

7504 0L Modeling wet chemical etching of surface flaws on fused silica [7504-29]

M. D. Feit, T. I. Suratwala, L. L. Wong, W. A. Steele, P. E. Miller, J. D. Bude, Lawrence Livermore National Lab. (United States) 
7504 0M Modeling of light intensification by conical pits within multilayer high reflector coatings [7504-28]

S. R. Qiu, J. E. Wolfe, Lawrence Livermore National Lab. (United States); A. M. Monterrosa, Univ. of California, Berkeley (United States); M. D. Feit, Lawrence Livermore National Lab. (United States); T. V. Pistor, Panoramic Technology Inc. (United States); C. J. Stolz, Lawrence Livermore National Lab. (United States)

\section{MINI-SYMPOSIUM: FEMTOSECOND LASER DAMAGE}

$75040 \mathrm{~N} \quad$ Analysis in wavelength dependence of electronic damage [7504-30]

M. Jupé, L. Jensen, K. Starke, D. Ristau, Laser Zentrum Hannover e.V. (Germany); A. Melninkaitis, V. Sirutkaitis, Vilnius Univ. (Lithuania)

$75040 \mathrm{O}$ Time-resolved digital holography: a versatile tool for femtosecond laser-induced damage studies [7504-31]

A. Melninkaitis, T. Balčiūnas, A. Vanagas, V. Sirutkaitis, Vilnius Univ. (Lithuania)

$75040 \mathrm{P} \quad$ Fundamental processes controlling the single and multiple femtosecond pulse damage behavior of dielectric oxide films [7504-32]

L. A. Emmert, D. N. Nguyen, M. Mero, W. Rudolph, The Univ. of New Mexico (United States); D. Ristau, K. Starke, M. Jupé, Laser Zentrum Hannover e.V. (Germany); C. S. Menoni, D. Patel, E. Krous, Colorado State Univ. (United States)

7504 0Q Subpicosecond pulse laser damage behavior of dielectric thin films prepared by different techniques [7504-33]

B. Mangote, L. Gallais, M. Commandré, M. Zerrad, J. Y. Natoli, M. Lequime, Institut Fresnel, CNRS, Univ. Aix Marseille (France)

7504 OR Mixed metal dielectric gratings for pulse compression applications [7504-53] J. Néauport, S. Palmier, CEA CESTA (France); N. Bonod, Institut Fresnel, CNRS, Univ. Aix Marseille (France); E. Lavastre, CEA CESTA (France); N. Baclet, CEA LITEN (France); G. Dupuy, CEA CESTA (France)

7504 OS Thin film femtosecond laser damage competition [7504-54]

C. J. Stolz, Lawrence Livermore National Lab. (United States); D. Ristau, M. Turowski, H. Blaschke, Laser Zentrum Hannover e.V. (Germany)

\section{SURFACES, MIRRORS, AND CONTAMINATION}

7504 0T Aspects of laser optics qualification for space applications (Invited Paper) [7504-55] W. Riede, P. Allenspacher, H. Schröder, P. Mahnke, G. Paunescu, Deutsches Zentrum für Luft- und Raumfahrt e.V. (Germany); D. Wernham, ESA / ESTEC (Netherlands)

$75040 \mathrm{U}$ The effects on glass surfaces of shrapnel and debris emissions from Petawatt laser driven solid targets [7504-56]

J. E. Andrew, K. A. Wallace, Atomic Weapons Establishment plc (United Kingdom)

$75040 \mathrm{~V}$ Impact of outgassing organic contamination on laser-induced damage of optics [7504-57] K. Bien-Aimé, CEA (France) and ICMCB, CNRS (France); A. Pereira, CEA (France); C. Belin, UMR 5255, ISM-CNRS (France); L. Gallais, Institut Fresnel, CNRS, Univ. Aix Marseille (France); P. Grua, I. Tovena-Pecault, J. Néauport, CEA (France); E. Fargin, ICMCB, CNRS (France)

7504 0W Chemical characterizations of optical materials: a tool for high quality components [7504-58] C. Ambard, O. Rondeau, CEA Le Ripault (France); J. Destribats, P. Cormont, J. Néauport, CEA CESTA (France)

$75040 \mathrm{X} \quad$ Laser damage precursors in fused silica [7504-59]

P. E. Miller, T. I. Suratwala, J. D. Bude, T. A. Laurence, N. Shen, W. A. Steele, M. D. Feit, J. A. Menapace,

L. L. Wong, Lawrence Livermore National Lab. (United States) 
7504 OY Diagnostics tools for subsurface damage characterization of ground silica parts [7504-36] P. Cormont, J. Neauport, N. Darbois, J. Destribats, CEA CESTA (France); C. Ambard, O. Rondeau, CEA Le Ripault (France)

$75040 \mathrm{Z}$ Birefringence and residual stress induced by $\mathbf{C O}_{2}$ laser mitigation of damage growth in fused silica [7504-37]

L. Gallais, Institut Fresnel, CNRS, Univ. Aix Marseille (France); P. Cormont, J. L. Rullier, CEA CESTA (France)

750410 Residual stress and damage-induced critical fracture on $\mathbf{C O}_{2}$ laser treated fused silica [7504-60]

M. J. Matthews, J. S. Stolken, R. M. Vignes, M. A. Norton, S. Yang, J. D. Cooke, G. M. Guss, J. J. Adams, Lawrence Livermore National Lab. (United States)

750411 Study of $\mathbf{C O}_{2}$ laser smoothing of surface roughness in fused silica [7504-62]

N. Shen, M. J. Matthews, J. E. Fair, J. A. Britten, H. T. Nguyen, J. D. Cooke, S. Elhadj, W. D. Henshaw, G. M. Guss, I. L. Bass, S. T. Yang, Lawrence Livermore National Lab. (United States)

750412 The effect of pulse duration on the growth rate of laser-induced damage sites at $351 \mathrm{~nm}$ on fused silica surfaces [7504-61]

R. A. Negres, M. A. Norton, Z. M. Liao, D. A. Cross, J. D. Bude, C. W. Carr, Lawrence Livermore National Lab. (United States)

750414 Magnetorheological finishing (MRF) of potassium dihydrogen phosphate (KDP) crystals: nonaqueous fluids development, optical finish, and laser damage performance at $1064 \mathbf{n m}$ and $532 \mathbf{n m}$ [7504-63] J. A. Menapace, P. R. Ehrmann, R. C. Bickel, Lawrence Livermore National Lab. (United States)

\section{MATERIALS AND MEASUREMENTS}

750415 Nonlinear spectroscopy: absorption and refraction (Best Oral Paper Award, Invited Paper) [7504-64] E. Van Stryland, D. Hagan, S. Webster, L. Padilha, College of Optics and Photonics, Univ. of Central Florida (United States)

750416 Ultrafast photoluminescence as a diagnostic for laser damage initiation [7504-65]

T. A. Laurence, J. D. Bude, N. Shen, P. E. Miller, W. A. Steele, G. Guss, J. J. Adams, L. L. Wong, M. D. Feit, T. I. Suratwala, Lawrence Livermore National Lab. (United States)

750417 Photoluminescence and photothermal deflection measurements in KDP crystals for high power applications [7504-66]

A. Ciapponi, F. Wagner, J.-Y. Natoli, Institut Fresnel, CNRS, Univ. Aix Marseille (France); B. Bertussi, F. Guillet, CEA, Le Ripault (France)

750418 Imaging system to measure kinetics of material cluster ejection during exit-surface damage initiation and growth in fused silica [7504-67]

R. N. Raman, R. A. Negres, S. G. Demos, Lawrence Livermore National Lab. (United States)

750419 High temperature thermographic measurements of laser heated silica [7504-68]

S. Elhadj, S. T. Yang, M. J. Matthews, D. J. Cooke, J. D. Bude, M. Johnson, M. Feit, V. Draggoo, Lawrence Livermore National Lab. (United States); S. E. Bisson, Sandia National Labs. (United States)

7504 1A Early thermal damage in optical coatings identified by infrared spectral signatures [7504-69] S. S. Kim, N. T. Gabriel, W. S. Chan, J. J. Talghader, Univ. of Minnesota (United States)

7504 1B Process for rapid detection of fratricidal defects on optics using linescan phase-differential imaging [7504-70]

F. L. Ravizza, M. C. Nostrand, L. M. Kegelmeyer, R. A. Hawley, M. A. Johnson, Lawrence Livermore National Lab. (United States) 
7504 1C Laser-induced surface damage density measurements of fused silica optics: a parametric study [7504-71] L. Lamaignère, S. Reyné, T. Donval, R. Courchinoux, J.-C. Poncetta, CEA CESTA (France); B. Bertussi, CEA, Le Ripault (France); H. Bercegol, CEA CESTA (France)

7504 1D Numerical analysis of laser-induced damage threshold search algorithms and their uncertainty [7504-42] A. Melninkaitis, G. Batavičiūtè, V. Sirutkaitis, Vilnius Univ. (Lithuania)

7504 1E Spot-size dependence of the LIDT from the NIR to the UV [7504-43]

L. Jensen, S. Schrameyer, M. Jupé, H. Blaschke, D. Ristau, Laser Zentrum Hannover e.V. (Germany)

7504 1F Adaptive laser-induced damage detection [7504-44]

A. Melninkaitis, J. Mirauskas, V. Sirutkaitis, Vilnius Univ. (Lithuania)

7504 1G Optical damage testing at the Z-Backlighter facility at Sandia National Laboratories [7504-45]

M. Kimmel, P. Rambo, R. Broyles, M. Geissel, J. Schwarz, J. Bellum, B. Atherton, Sandia National Labs. (United States)

7504 1H Angle resolved scattering: a method for in situ investigations of laser-induced damage? [7504-82] S. Schröder, T. Herffurth, A. Duparré, Fraunhofer-Institut für Angewandte Optik und Feinmechanik (Germany)

7504 1I Life testing for laser optics: a first look [7504-72]

J. W. Arenberg, Northrop Grumman Aerospace Systems (United States)

7504 1J Damage and degradation of optics and sensors under intense EUV radiation from a table-top laser produced plasma source [7504-73]

F. Barkusky, A. Bayer, B. Flöter, C. Peth, K. Mann, Laser-Lab. Göttingen e.V. (Germany)

$75041 \mathrm{~K} \quad$ Modeling laser conditioning of KDP crystals [7504-74]

G. Duchateau, CEA (France)

7504 1L Laser conditioning process combining N/1 and S/1 programs to improve the damage resistance of KDP crystals [7504-75]

Y. Zhao, Shanghai Institute of Optics and Fine Mechanics (China); G. Hu, Shanghai Institute of Optics and Fine Mechanics (China) and the Graduate School of the Chinese Academy of Sciences (China); J. Shao, Shanghai Institute of Optics and Fine Mechanics (China); X. Liu, Shanghai Institute of Optics and Fine Mechanics (China) and the Graduate School of the Chinese Academy of Sciences (China); H. He, Z. Fan, Shanghai Institute of Optics and Fine Mechanics (China)

$75041 \mathrm{M} \quad$ Nanosecond-laser induced damage at $1064 \mathrm{~nm}, 532 \mathrm{~nm}$, and $355 \mathrm{~nm}$ in $\mathrm{LiB}_{3} \mathrm{O}_{5}$ [7504-76]

F. R. Wagner, Institut Fresnel, CNRS, Univ. Aix Marseille (France); A. Hildenbrand, Institut franco-allemand de recherches de Saint-Louis (France); J.-Y. Natoli, M. Commandre, Institut Fresnel, CNRS, Aix-Marseille Univ. (France)

$75041 \mathrm{~N} \quad$ Laser induced damage of sapphire and titanium doped sapphire crystals under femtosecond to nanosecond laser irradiation [7504-77]

B. Bussière, LP3 Pôle Scientifique et Technologique de Luminy (France), Amplitude Technologies (France), and Institut Fresnel, CNRS, Univ. Aix Marseille (France); O. Utéza, N. Sanner, M. Sentis, LP3 Pôle Scientifique et Technologique de Luminy (France); G. Riboulet, L. Vigroux, Amplitude Technologies (France); M. Commandré, F. Wagner, J.-Y. Natoli, Institut Fresnel, CNRS, Univ. Aix-Marseille (France); J.-P. Chambaret, Ecole Nationale Supérieure de Techniques Avancées (France)

$75041 \mathrm{O} \quad$ Deterministic single shot and multiple shots bulk damage thresholds for doped and undoped crystalline and ceramic YAG [7504-78]

B. T. Do, Sandia National Labs. (United States); A. V. Smith, AS-Photonics (United States)

$75041 \mathrm{P}$ Study of haze in 193nm high dose irradiated $\mathrm{CaF}_{2}$ crystals [7504-50]

U. Natura, S. Rix, M. Letz, L. Parthier, SCHOTT AG (Germany) 
7504 1Q Development of large size $\mathbf{M g F}$ single crystal grown by the $\mathbf{C Z}$ method [7504-52]

M. Ariyuki, Y. Hashimoto, N. Mochizuki, Y. Inui, I. Masada, T. Nawata, Tokuyama Corp. (Japan); T. Fukuda, Fukuda X'tal Lab. (Japan)

7504 1R Laser-induced damage thresholds in silica glasses at different temperatures [7504-47]

K. Mikami, Osaka Univ. (Japan); S. Motokoshi, M. Fujita, Institute for Laser Technology (Japan); T. Jitsuno, J. Kawanaka, Osaka Univ. (Japan); R. Yasuhara, Hamamatsu Photonics K. K. (Japan)

Abstracts

Participant List

Author Index 


\section{International Program Committee}

The cochairs of this series of symposia rely heavily on an International Program Committee to ensure their awareness of significant research in the broad field of laser-induced damage throughout the world. Its members are also frequently the source of suggestions for invited speakers and mini-symposium topics and leaders. The committee performs a vital service as an outreach for the conference on a global scale. Individuals with suggestions for the meeting are requested to contact any committee member (next page) who is either an acquaintance or in close proximity. The committee is ably led by Detlev Ristau, International Program Committee Chair.

Gregory J. Exarhos (greg.exarhos@pnl.gov)

Vitaly E. Gruzdev (gruzdevv@missouri.edu)

Detlev Ristau (dr@lzh.de)

M. J. Soileau (mj@mail.ucf.edu)

Christopher J. Stolz (stolz1@llnl.gov) 


\section{International Program Committee}

Detlev Ristau, Chair

Laser Zentrum Hannover e.V.

Laser Components Dept

Hollerithallee 8

Hannover, 30419 Germany

James E. Andrew

Atomic Weapons Establishment Plc

Bldg C15-1

Aldermaston

Reading Berks RG7 4PR United Kingdom

Jonathan Arenberg

Northrop Grumman Aerospace Systems

Bldg R8/2789

1 Space Park Blvd

Redondo Beach, CA 90278-1001

310813 2567; jon.arenberg@ngc.com

Hervé Bercegol

CEA-CESTA

BP2

15 ave des Sablieres

Le Barp, 33114 France

Mireille Commandré

Institut Fresnel ENSPM

CNRS EGIM

Domaine de Saint Jerôme

Marseille Cedex 2013397 France

Stavros Demos

Lawrence Livermore National Lab.

L-491

7000 East Ave

Livermore, CA 94550-9698

925423 3388; demos1@llnl.gov

Jerome B. Franck

U.S. Army Night Vision \& Electronic Sensors

Directorate

10221 Burbeck Rd

Fort Belvoir, VA 22060-5806 USA
Leonid B. Glebov

College of Optics and Photonics, Univ. of Central Florida

4000 Central Florida Blvd.

Orlando, FL 32816-8005 USA

Klaus Mann

Laser-Laboratorium Göttingen e.V.

Hans-Adolf-Krebs-Weg

37077 Göttingen Germany

Masataka Murahara

Tokai University

Electrical Engineering Dept.

1117 Kitakaname

Hiratsuka-shi Kanagawa 259-1292 Japan

Semyon Papernov

University of Rochester

Laboratory of Laser Energetics

250 East River Rd.

Rochester, NY 14623-1299 USA

Amy L. Rigatti

University of Rochester

Laboratory for Laser Energetics

250 East River Rd.

Rochester, NY 14632-1299 USA

Jianda Shao

Shanghai Institute of Optics and Fine Mechanics No 390 Qinghe Rd, Jiading

Shanghai, 201800 China

Michelle Shinn

Thomas Jefferson National Accelerator Facility

Free Electron Laser Div

12000 Jefferson Ave

Newport News, VA 23606-4350

Kunio Yoshida

Osaka Institute of Technology

5-16-1, Ohmiya, Asahi-ku

Osaka 535-8585 Japan 


\title{
Symposium Welcome
}

\author{
On the occasion of the SPIE Laser Damage (41 st Boulder Damage) Symposium \\ Vitaly Gruzdev \\ University of Missouri (United States)
}

On behalf of my fellow co-chairs, M. J. Soileau, Gregory Exarhos, Detlev Ristau, and Christopher Stolz, I extend a hearty welcome to all participants of the $41^{\text {st }}$ Annual Symposium on Optical Materials for High Power Lasers held at the NIST facility in Boulder, Colorado. The conference starts its fifth decade under the new official name - SPIE Laser Damage Symposium. This change was motivated by the strong need to adjust the name with the real content of the symposium, to maintain its status and to provide better referencing to it for online search via internet search engines. In this connection it is important to note that the previous names - both official (Annual Symposium on Optical Materials for High-Power Lasers) and unofficial (Boulder Damage Symposium) - do not include the proper combination of the two key words - laser damage. This does not hurt the very high status of the conference among the laser-damage community because since the first meeting organized by its co-founders - Art Guenther and Alex Glass in 1969 it has been performing the role of major international platform for lively discussions and communications between researchers and engineers from academics, industry, and military related to all aspects of laser-induced damage. Fluctuating from year to year, the number of presentations has the strong trend to increase (Fig. 1) indicating the enormous vitality of this field and the continuously growing interest to the related topics. Proceedings of the Boulder Damage Symposium (BDS) have become the most complete and major resource of information on laser damage and multiple related areas compiled since the early stages of that field. The 40-year collection of the proceedings (from 1969 to 2008 inclusive) has been published in a single DVD distributed among participants of the last year's symposium. The tremendous efforts of the authors to prepare the manuscripts for this series of proceedings of SPIE help to maintain the unique status of the proceedings and are gratefully acknowledged here.

Significant contribution to the success of the BDS has been done by the international program committee representing leading research centres and groups of the laser-damage community worldwide. Presently, the committee consists of representatives from the UK, Germany, France, Japan, China, and the United States of America. Besides providing contributions to the conference program, the international program committee is also active in promoting the conference and in attracting researchers from around the world. The engagement of the committee has initiated participation from more than 30 countries including America, Europe, Asia, Africa, and including Australia during the last decade is acknowledged here as being very important.

Following the 40-year tradition, the conference addresses four core topics including materials and measurements, fundamental mechanisms, thin films as well as surfaces, mirrors, and contamination. One invited presentation is delivered for each of the topics to provide an overview of particular research directions and educate the younger generation of conference participants. In order to track the current trends in research and further intensify the scientific dialogue at the BDS, a mini-symposium dedicated to a hot current topic in laser material interaction has been organized every year since 1992. This year's mini-symposium on "Femtosecond laser damage" is chaired by Dr. Wolfgang Rudolf from the University of New Mexico and has attracted a large number of interesting contributions from industrial companies and research institutes from France, the United States, and Germany.

Continuing the success of the damage competition held the first time in 2008, Chris Stolz kindly organized another competition with the target to review the present state of the art in multilayer coatings for femtosecond-laser optics. This initiative found a broad resonance within the community and resulted in 28 samples submitted by companies and research institutes from China, Japan, Germany, and the United States of America. Sample testing was performed by 
the group with Detlev Ristau at Laser Zentrum Hannover e.V. (Germany), who accomplished an enormous amount of work by evaluating femtosecond laser-induced damage threshold of all the samples. This outstanding effort is appreciated by the community, and the organizers acknowledge this special contribution by Chris Stolz and Detlev Ristau. Chris Stolz delivered a talk about the competition at the mini-symposium and has prepared a summary paper on the competition which can be found in the present volume of the conference proceedings.

One of the young traditions of the symposium is to acknowledge authors of who presented notable results at the previous year's meeting. The authors receive best-paper awards consisting of a cut-glass piece of art with symposium emblem and date and names of the authors embedded into the glass by controlled laser-induced damage made with focused beam from a Q-switched laser. Bearing in mind the experience of the previous years, a new rule has been introduced starting from this year: for the awarded authors it is mandatory to prepare and publish manuscripts of their presentations in the conference proceedings.

Much of the success of the meeting can be attributed to the untiring efforts of the SPIE staff as well as Jenessa Huffman from Lawrence Livermore National Lab (Symposium Assistant). The organizers also acknowledge the support of the NIST staff and especially Kent Rochford (NIST Coordinator) for coordinating activities and arranging for the audio-video facilities in the meeting room. We gratefully appreciate the annual co-sponsoring from the Lawrence Livermore Laboratory's significant support of this meeting. The contribution of Laser Zentrum Hannover e.V. (Germany) in performing the laser damage tests for the competition is greatly appreciated. We appreciate support from Pacific Northwest National Laboratory and Office of Naval Research. We also acknowledge the other cooperating organizations: School of Optics - CREOL and FPCE, College of Optics and Photonics, University of Central Florida, and the University of Missouri. 


\title{
Summary of Meeting
}

\author{
Laser-Induced Damage in Optical Materials \\ $41^{\text {st }}$ Annual Symposium \\ 21-23 September 2009 \\ Christopher J. Stolz \\ Lawrence Livermore National Laboratory \\ PO Box 808, L-491 \\ Livermore, CA 94551 USA
}

\begin{abstract}
1. Abstract
These proceedings contain the papers presented as oral and poster presentations at the $41^{\text {st }}$ Annual Symposium on Optical Materials for High-Power Lasers. The conference was held at the National Institute of Standards and Technology facility in Boulder Colorado on 21-23 September 2009. The symposium was divided into the traditional sessions devoted to the following topics: thin films; surfaces, mirrors and contamination; fundamental mechanisms; materials and measurements; and finally, a mini-symposium on "Femtosecond laser-induced damage" which included a thin film femtosecond laser damage competition. A roundtable discussion was introduced this year on the topic of "Experimental identification of fundamental LIDT mechanisms: techniques, challenges, and new approaches". The conference was opened by Dr. Vitaly Gruzdev with a symposium welcome. Dr. Gregory J. Exarhos of Pacific Northwest National Laboratory (USA), Dr. Vitaly Gruzdev of the University of Missouri, Columbia (USA), Dr. Detlev Ristau of the Laser Zentrum Hannover e.V. (Germany), Dr. M. J. Soileau, of the University of Central Florida (USA), and Mr. Christopher J. Stolz of the Lawrence Livermore National Laboratory (USA), co-chaired the symposium. The founding organizers are Dr. Arthur H. Guenther and Dr. Alexander J. Glass.
\end{abstract}

All told, 72 papers were presented, including oral and poster presentations plus a mini-symposium. No parallel sessions were held, allowing the opportunity to discuss common research interests with all the presenters. With 139 registered participants, the meeting offered an opportunity to make many new acquaintances. Although held annually in the US, this is a truly International conference with 33 percent of the attendees and 57 percent of the presentations coming from abroad. As usual, the National Institute of Standards and Technology in Boulder, Colorado, offered a setting conductive to interchanges between individuals working in closely related and complementary fields. We look forward to future opportunities to come together again in this setting.

The 42 ${ }^{\text {nd }}$ Annual Symposium of this series will be held in Boulder, Colorado, 27-29 September 2010. A concerted effort will be made to ensure a close liaison between the high-peak-power and high-average-power communities, as well as to include damage issues related to various research efforts and commercial laser applications. A minisymposium on laser ablation and applications will occur. Invited talks are also anticipated to open the four major topical areas.

The principal topics to be considered as contributed papers in 2010 do not differ drastically from those enumerated above. We expect to hear more about the impacts of contamination on the laser resistance of optical components and the impacts of surface and material defects since both of these topics continue to generate significant interest. Highenergy laser windows, crystals, and transparent ceramics continue to place limitations on laser systems so remain active areas of research and spirited debate. Refinement of the mitigation strategy consisting of damage initiation followed by arresting damage growth through post-processing techniques while not creating downstream damage is also expected to be a continued focus as a large number of laser-resistant UV optics are manufactured for various international largeaperture fusion lasers. Short pulse laser optics and damage phenomena remain an active area of research. We also expect to hear more about new measurement techniques to improve our understanding of the different damage mechanisms or to improve the manufacturing of optical materials and thin films for optical components of greater laser damage resistance. 
As was initially established in 1992, several distinguished invited speakers will make presentations of a tutorial or review nature, in addition, other contributors will cover late-breaking developments of interest to the attendees. The purpose of this series of symposia is to exchange information about optical materials for high-power / high-energy lasers. The editors welcome comments and criticism from all interested readers relevant to this purpose.

Key words: laser damage, laser interaction, optical components, optical fabrication, optical materials and properties, thin film coatings, contamination, metrology, fundamental mechanisms.

\section{Introduction}

The 41st Annual Symposium on Optical Materials for High-Power Lasers (a.k.a. the Boulder Damage Symposium, because of its Boulder, Colorado, venue, and this year now named the SPIE Laser Damage Symposium) was held 2123 September 2009. This symposium continues to be the principal U.S. and International forum for the exchange of information relative to the interaction of intense laser light with optical media and components. Historically, the meeting has been divided into four broad categories: thin films; fundamental mechanisms; materials and measurements; and surfaces, mirrors, and contamination as illustrated in figure 1.

\section{Cochairs}

The Boulder Damage Symposium was founded by Dr. Arthur H. Guenther and Alexander Glass. Over the last 41 years many prominent leaders within the high power laser community have contributed significantly as cochairs to this conference. A historical timeline of their contributions are listed below:

1969 A. J. Glass, A. H. Guenther (C. M. Stickley)

1979 add H. E. Bennett and B. E. Newnam

1981 add D. Milam; A. J. Glass departs

1987 add M. J. Soileau

1988 D. Milam departs

1989 add L. L. Chase

1994 L. L. Chase departs; add M. R. Kozlowski

1997 add G. J. Exarhos, K. L. Lewis; H. E. Bennett and B. E. Newnam depart

2001 add C. J. Stolz

2002 add N. Kaiser; M. R. Kozlowski departs

2004 N. Kaiser departs

2005 add D. Ristau

2007 A. H. Guenther deceased

2008 K. L. Lewis departs 
Boulder conference attendence statistics

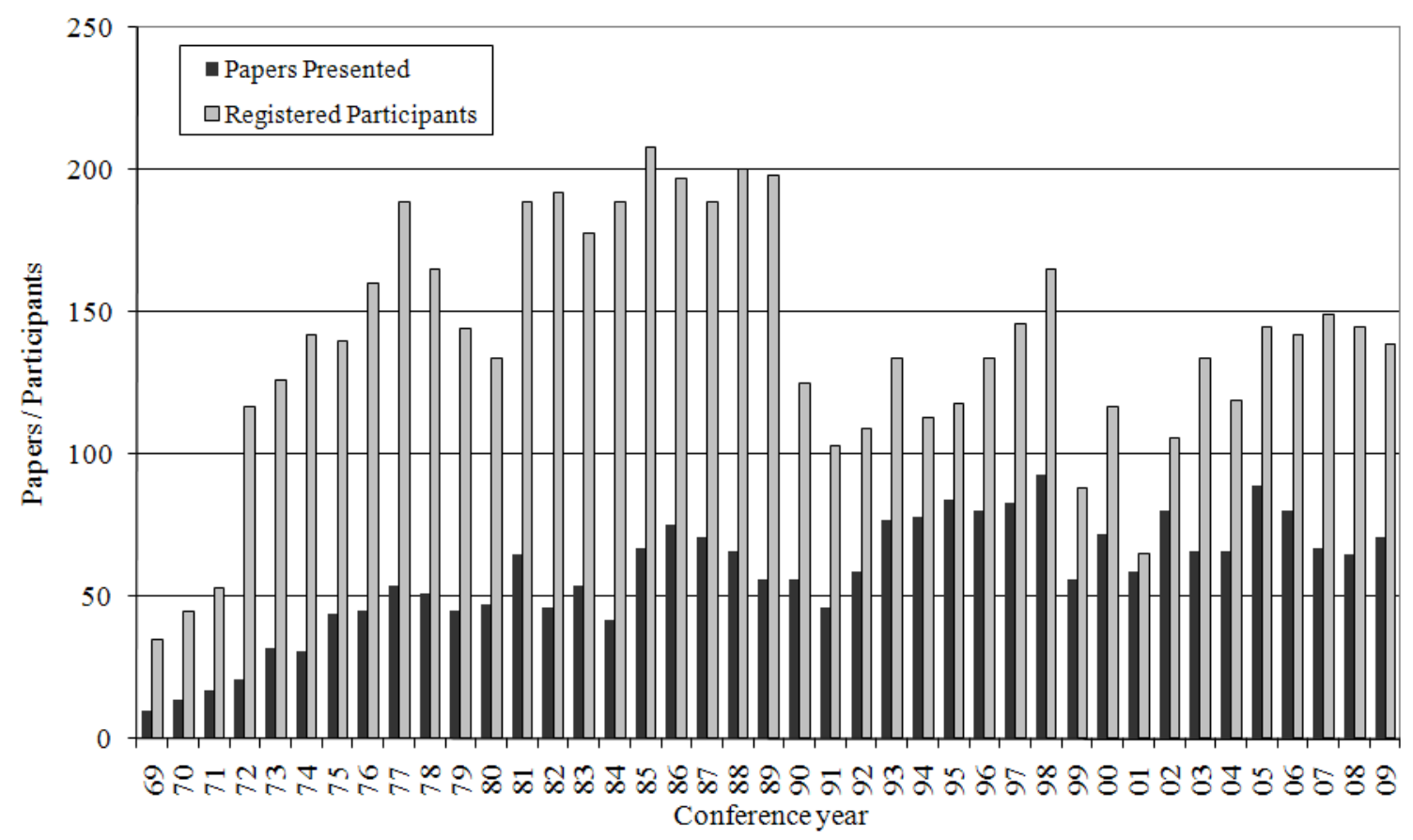

Topical emphasis of conference by year

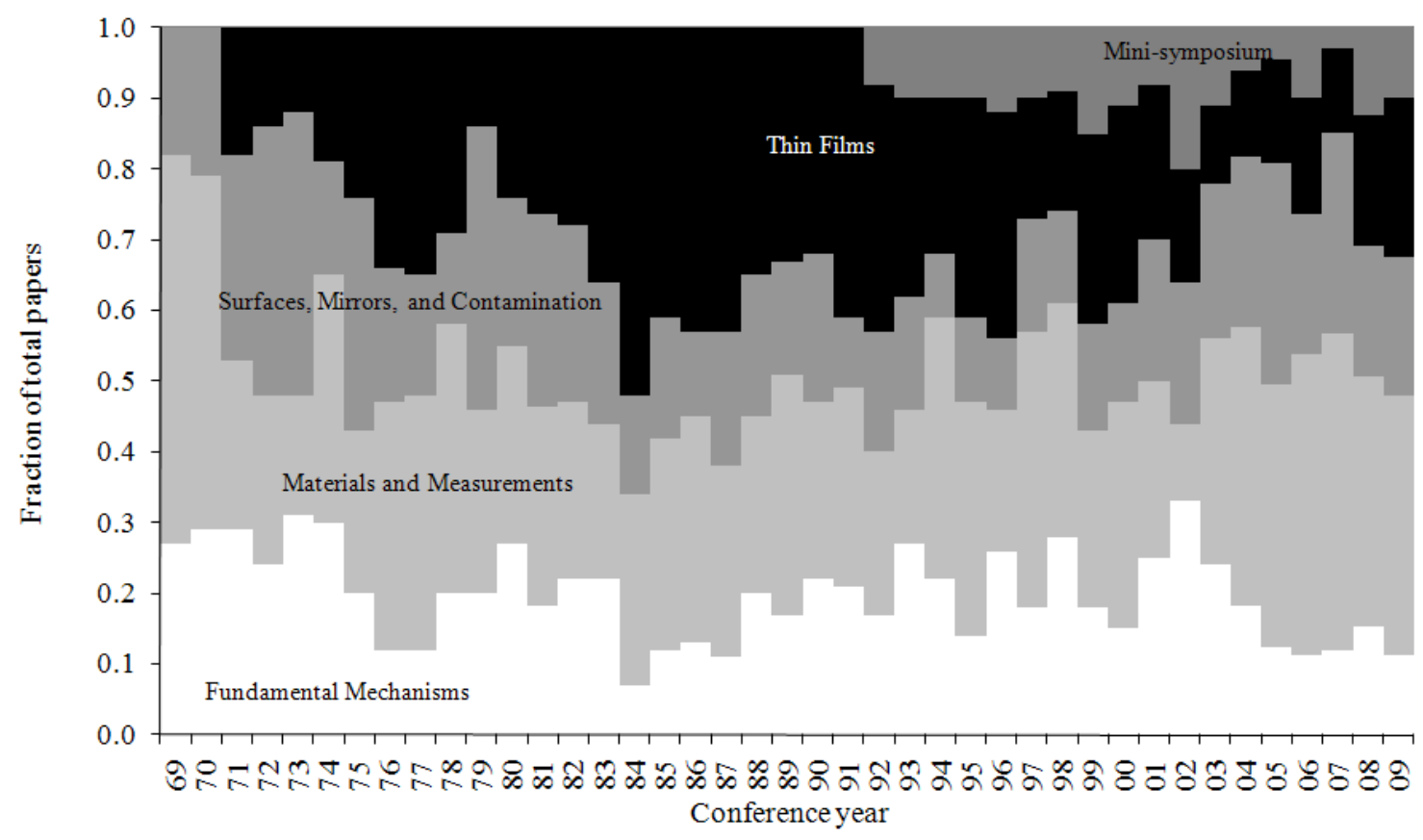

Fig. 1 Historical statistics of conference attendance and paper submission (top) and distribution of submissions by topical area (bottom). 


\section{Thin Films}

Because of the tremendous range of applications of optical multilayers for modifying the optical performance of elements (e.g., reflectivity, wavelength sensitivities, polarization, or simply protection, etc.), this receives attention. Besides damage thresholds or sensitivity, topics include advanced thin deposition technology, film structure, film design, film response to environmental attack and aging, and numerous reports on important film properties such as adhesion, thermal conductivity, absorption, stability, defect identification, aging - drift and moisture infusion, and conditioning processes to improve performance.

UV and shot pulse coatings dominated this session reflecting work currently being done in UV lithography, laser fusion, and ultrafast lasers. The thin film damage competition started in 2008 was continued to increase understanding and as a means to solicit more participation from the private sector and rejuvenate interest in this topic. $786 \mathrm{~nm}$ high reflectors were tested at 180 fs with damage thresholds ranging from 0.2 to $1.1 \mathrm{~J} / \mathrm{cm}^{2}$ to complement the theme of the minisymposium. A multitude of deposition processes, coating materials, and manufacturing techniques submitted to this competition provided some interesting results and contrast to last year's nanosecond damage results.

\section{Fundamental Mechanisms}

This area deals with the interaction of light with matter - where real system experience is presented. Topics include nonlinear behavior, self-focusing, thermal modeling, and experimental data reduction protocols (e.g. effects of pulse width, repetition rate or duty cycle, spot size, wavelength, temperature, ionizing radiation, and other environmental effects), as well as all types of experimental or material variable scaling relationships that not only afford insight into the fundamentals of the interaction process, but allow extrapolations for engineering and cost-benefit evaluations. In many areas, these insights are based on real-world, systems-level tests, as opposed to a frequently pristine laboratory environment.

The emphasis this year was on understanding the role and behavior of defects within optical materials and surfaces with an emphasis on either short wavelengths (UV) or short pulses (fs). The fundamental nature of the minisymposium topic reduced the size of this session.

\section{Surfaces and Mirrors}

Here one will find presentations on surface preparation (including single-point diamond micro-machining and ductile grinding), subsurface damage characterization, roughness and scattering, environmental degradation and aging, as well as substrate material properties, including cooling techniques, and, of course, damage measurements and the cleaning of surfaces. The crux of the contamination problem is fundamentally that damage experiments done in controlled clean laboratory settings do not necessarily yield the same results as laser operations in less pristine operating environments. There is a significant amount of work needed in understanding what contamination is acceptable, what contamination is threatening to optic survivability, and how fluence-limiting or lifetime-limiting contamination can be eliminated or mitigated from operating laser systems.

Damage of fused silica optical surfaces at $351 \mathrm{~nm}$ remains a very active area of research within the international laser fusion community. Studies emphasize understanding precursors and potential mitigation techniques to arrest growth of initiated damage without causing downstream modulation which could damage downstream optics.

\section{Materials and Measurements}

This section deals with laser damage to the bulk of transparent optical media - whether amorphous, polymeric, polycrystalline, or crystalline - and its preparation, as well as reports of material properties of import to their optical function and / or the damage process, e.g., linear and nonlinear refractive indices, absorption, thermal conductivity, 
stress-optic coefficients, moduli, and defects. Also included are new techniques for measuring these quantities, which present a continuing challenge as materials are improved in quality and diversity.

There is always interest in improved measurement systems or new instruments particularly in the area of photothermal or photoluminescence non-destructive defect characterization. A number of different optical materials such as $\mathrm{CaF}_{2}$, fused silica, $\mathrm{KDP}, \mathrm{MgF}_{2}$ sapphire, and ceramics are also being studied and reported. Finally a new instrument for measuring nonlinear absorption in optical materials over a wide spectral range was introduced.

\section{Mini-Symposium on Femtosecond Laser-Induced Damage}

This year the meeting was concluded with a small mini-symposium dealing with the topic of femtosecond laser-induced damage. This material is critical in high power laser systems as a laser resistant transparent material used for beam focusing and environmental barrier. The talks covered a multitude of topics covering both bulk and surface properties, defects, damage mechanisms over a wide range of pulse lengths, and finally the challenges associated with characterization of this unique material. The mini-symposium was organized this year by Wolfgang Rudolph from the University of New Mexico (USA). A brief summary of the past mini-symposium topics starting in 1992 and the organizing chairs are listed below.

\begin{tabular}{|c|c|c|}
\hline Year & Chair & Topic \\
\hline 1992 & Brian Newnam & Damage Issues for Lithographic Optics \\
\hline 1993 & Karl Guenther & $\begin{array}{l}\text { Quest for the Invincible Laser Coating -- Critical Review of Pulse } \\
\text { Laser Induced Damage to Optical Coatings: Causes and Cures }\end{array}$ \\
\hline 1994 & Claude Klein & Diamond for Optics Applications in Adverse Environments \\
\hline 1995 & Floyd Hovis & Contamination and the Laser Damage Process \\
\hline 1996 & Robert Setchell & Laser-Induced Damage in Optical Fibers \\
\hline 1997 & David Welch & Damage and Lifetime Issues for Laser Diodes \\
\hline 1998 & Norbert Kaiser & Optics for the Deep UV \\
\hline 1999 & David Sliney & Laser Damage Processes in the Eye and Other Biological Tissue \\
\hline 2000 & $\begin{array}{l}\text { Mark Kozlowski } \\
\text { Hideo Hosono }\end{array}$ & Defects in Glass \\
\hline 2001 & Mark Kozlowski & Optical Materials for Telecommunications \\
\hline 2002 & Detlev Ristau & $\begin{array}{l}\text { Optics Characterization -joint with 7th International Workshop of } \\
\text { Laser Beam and Optics Characterization. }\end{array}$ \\
\hline 2003 & William Latham & Understanding Optical Damage with Ultra-short Laser Pulses \\
\hline 2004 & Keith Lewis & Damage Issues in Fiber Laser Systems \\
\hline 2005 & Leon Glebov & Petwatt Lasers \\
\hline 2006 & Alan Stewart & Optics in a Hostile Environment \\
\hline 2007 & Stan Peplinski & Lifetime Issues for CW and Quasi CW Lasers \\
\hline 2008 & $\begin{array}{l}\text { Christopher Stolz } \\
\text { Hervé Bercegol }\end{array}$ & Fused Silica \\
\hline 2009 & Wolfgang Rudolph & Femtosecond Laser-Induced Damage \\
\hline
\end{tabular}

\section{Invited Talks}

As usual, the 2009 meeting was highlighted by several invited presentations. They included:

1. "Mirror characterization in the LIGO 4km interferometers," Rana Adhikari, California Institute of Technology (USA).

2. "Ultrafast laser-induced modifications of energy bands of non-metal crystals," Vitaly Gruzdev, University of Missouri, Colombia (USA), paper 7504-27 / 75040G. 
3. "Aspects of laser optics qualification for space applications," Wolfgang Riede, Deutsches Zentrum für Luft-und Raumfahrt e.V. (Germany), paper 7504-55 / 75040T.

4. "Nonlinear optical spectroscopy: absorption and refraction," Eric W. Van Stryland, College of Optics and Photonics, University of Central Florida (USA), paper 7504-64 / 750415.

\section{Conference Awards}

Beginning with the meeting in 2000, the organizers instituted a best paper award in the oral and poster categories. The awards appropriately take the form of laser-induced art in an optical glass plaque. (see, e.g., paper by I. N. Trotski, Proc. SPIE 4679, 392-399 (2001)).

There were several outstanding posters and oral papers, however, the following papers were selected:

Best oral paper:

"Nonlinear spectroscopy: absorption and refraction," Eric Van Stryland, David Hagan, Scott Webster, Lazaro Padilha, College of Optics and Photonics, University of Central Florida (USA), paper 7504-65 / 750415.

Best poster paper:

"Influence of Na-related defects on DUV nonlinear absorption in $\mathrm{CaF}_{2}$ : nanosecond versus femtosecond laser pulses," Ch. Mühlig, H. Stafast, W. Triebel, Th. Zeuner, Ch. Karras, Institute of Photonic Technology, (Germany), M. Letz, SCHOTT AG Research and Technology Development (Germany), paper 7504-3 / 75040I.

\section{In Conclusion}

The location in Boulder, Colorado, during autumn at the venue of the National Institute of Standards and Technology and its outstanding facilities and support staff were appreciated by all. The 139 attendees were easily accommodated with ample opportunity to mingle and socialize.

The organizers of the Boulder Damage Symposium look for opportunities to join with other related groups for joint meetings in the future. For example, in 2002 we had a joint meeting with the $7^{\text {th }}$ International Workshop on Laser Beam and Optics Characterization, again with no parallel sessions.

We must also take note of the tireless assistance of SPIE staff who handle the administrative functions of the symposium. Their presence, experience, resources, and professionalism clearly were made manifest with on-line reservations, payment by credit cards, badges, preparation of the abstract book and pocket programs, and on-line document service, to which we may add the social functions - thanks to them, "A good time was had by all."

\section{Acknowledgments}

A number of volunteers help tirelessly with some of the administrative duties necessary to put on a conference of this magnitude. SPIE staff took care of all the administrative planning and on-site tasks including registration, setup, and general questions as well as the publication of all of the manuscripts into these proceedings.

Of course, we are all indebted to Kent Rochford, Division Chief of the Optoelectronics Division, who was the prime contact at NIST, for his continued support and encouragement, and Wendy Ortega, also of NIST, who together made it possible to hold a seamless meeting. On behalf of all the organizers and attendees, we thank them for their tireless efforts.

xviii 


\section{References}

\section{Books:}

A. J. Glass and A. H. Guenther, eds. Damage in Laser Glass, ASTM Spec. Tech. Pub. 469, ASTM, Philadelphia, PA (1969).

N. Bloembergen, Fundamentals of Damage in Laser Glass, National Materials Advisory Board Publ. NMAB-271, National Academy of Sciences (1970).

N. Bloembergen, High-Power Infrared Laser Windows, National Materials Advisory Board Publ. NMAB-356 (1971).

R. M. Wood, Laser-Induced Damage in Optical Materials, Adam Hilger, Bristol (UK) (1986).

M. J. Weber, ed., Handbook of Laser Science and Technology, Vol. III: Optical Materials, Part 1: Nonlinear Optical Properties/Radiation Damage, CRC, Boca Raton, FL (1986).

M. J. Weber, ed., Handbook of Laser Science and Technology, Vol. IV: Optical Materials, Part 2: Properties, CRC, Boca Raton, FL (1986).

M. J. Weber, ed., Handbook of Laser Science and Technology, Vol. V: Optical Materials, Part 3: Applications, Coatings, and Fabrication, CRC, Boca Raton, FL (1987).

R. M. Wood, Ed., Selected Papers on Laser Damage in Optical Materials, SPIE Milestone Series Vol. MS24, Bellingham, WA (U.S.) (1990).

M. R. Kozlowski, Damage-Resistant Laser Coatings, in Thin Films for Optical Systems, F. Flory, ed., Marcel Dekker, New York, 521-549 (1995).

M. J. Weber, ed., Handbook of Laser Science and Technology, Suppl. 2, Optical Materials, CRC, Boca Raton, FL, (1995).

A. H. Guenther, ed., International Trends in Applied Optics, SPIE Press monograph, Bellingham, Washington, Chapters 1, $3,8,9,10, \& 12$ (2002).

M. J. Weber, ed., Handbook of Optical Materials, CRC, Boca Raton, FL (2002).

R. M. Wood, The Power and Energy-Handling Capability of Optical Material, Components, and Systems, (Tutoriual Texts in Optical Engineering Vol TT60 A. R. Weeks Series Editor SPIE Press Bellingham WA) (2003).

R. M. Wood, Laser Induced Damage of Optical Materials (Institute of Physics Publishing, Bistrol, UK) (2003).

C. J. Stolz and F. Y. Génin, Laser Resistant Coatings, in Optical Interference Coatings, N. Kaiser and H. Pulker, eds., Springer-Verlag, Berlin, 310-333 (2003).

\section{Proceedings:}

A. J. Glass and A. H. Guenther, eds., Damage in Laser Materials, Nat. Bur. Stand. (U.S.) Spec. Publ. 341 (1970).

A. J. Glass and A. H. Guenther, Eds., Damage in Laser Materials: 1971, Nat. Bur. Stand. (U.S.) Spec. Publ. 356 (1971).

A. J. Glass and A. H. Guenther, eds., Laser-Induced Damage in Optical Materials: 1972, Nat. Bur. Stand. (U.S.) Spec. Publ. $372(1972)$.

A. J. Glass and A. H. Guenther, Eds., Laser-Induced Damage in Optical Materials: 1973, Nat. Bur. Stand. (U.S.) Spec. Publ. 387 (1973).

A. J. Glass and A. H. Guenther, eds., Laser-Induced Damage in Optical Materials: 1974, Nat. Bur. Stand. (U.S.) Spec. Publ. 414 (1974).

A. J. Glass and A. H. Guenther, eds., Laser-Induced Damage in Optical Materials: 1975, Nat. Bur. Stand. (U.S.) Spec. Publ. 435 (1975).

A. J. Glass and A. H. Guenther, eds., Laser-Induced Damage in Optical Materials: 1976, Nat. Bur. Stand. (U.S.) Spec. Publ. 462 (1976).

A. J. Glass and A. H. Guenther, eds., Laser-Induced Damage in Optical Materials: 1977, Nat. Bur. Stand. (U.S.) Spec. Publ. 509 (1977).

A. J. Glass and A. H. Guenther, eds., Laser-Induced Damage in Optical Materials: 1978, Nat. Bur. Stand. (U.S.) Spec. Publ. 541 (1978).

H. E. Bennett, A. J. Glass, A. H. Guenther, and B. E. Newnam, eds., Laser-Induced Damage in Optical Materials: 1979 , Nat. Bur. Stand. (U.S.) Spec. Publ. 568 (1979). 
H. E. Bennett, A. J. Glass, A. H. Guenther, and B. E. Newnam, eds., Laser-Induced Damage in Optical Materials: 1980, Nat. Bur. Stand. (U.S.) Spec. Publ. 620 (1981).

H. E. Bennett, A. J. Glass, A. H. Guenther, and B. E. Newnam, eds., Laser-Induced Damage in Optical Materials: 1981, Nat. Bur. Stand. (U.S.) Spec. Publ. 638 (1983).

H. E. Bennett, A. H. Guenther, D. Milam, and B. E. Newnam, eds., Laser-Induced Damage in Optical Materials: 1982, Nat. Bur. Stand. (U.S.) Spec. Publ. 669 (1984).

H. E. Bennett, A. H. Guenther, D. Milam, and B. E. Newnam, eds., Laser-Induced Damage in Optical Materials: 1983, Nat. Bur. Stand. (U.S.) Spec. Publ. 688 (1985).

H. E. Bennett, A. H. Guenther, D. Milam, and B. E. Newnam, eds., Laser-Induced Damage in Optical Materials: 1984, Nat. Bur. Stand. (U.S.) Spec. Publ. 727 (1986).

H. E. Bennett, A. H. Guenther, D. Milam, and B. E. Newnam, eds., Laser-Induced Damage in Optical Materials: 1985, Nat. Bur. Stand. (U.S.) Spec. Publ. 746 (1987).

H. E. Bennett, A. H. Guenther, D. Milam, and B. E. Newnam, eds., Laser-Induced Damage in Optical Materials: 1986, Nat. Bur. Stand. (U.S.) Spec. Publ. 752 (1987).

H. E. Bennett, A. H. Guenther, D. Milam, B. E. Newnam, and M. J. Soileau, eds., Laser-Induced Damage in Optical Materials: 1987, Nat. Bur. Stand. (U.S.) Spec. Publ. 756 (1988).

H. E. Bennett, A. H. Guenther, B. E. Newnam, and M. J. Soileau, eds., Laser-Induced Damage in Optical Materials: 1988, Nat. Bur. Stand. (U.S.) Spec. Publ. 775 (1989).

H. E. Bennett, L. L. Case, A. H. Guenther, B. E. Newnam, and M. J. Soileau, eds., Laser-Induced Damage in Optical Materials: 1989, NIST (U.S.) Spec. Publ. 801, ASTM STP 1117 and Proc. SPIE 1438 (1989).

H. E. Bennett, L. L. Case, A. H. Guenther, B. E. Newnam, and M. J. Soileau, eds., Laser-Induced Damage in Optical Materials: 1990, ASTM STP 1141 and Proc. SPIE 1441 (1991).

H. E. Bennett, L. L. Case, A. H. Guenther, B. E. Newnam, and M. J. Soileau, eds., Laser-Induced Damage in Optical Materials: 1991, Proc. SPIE 1624 (1992).

H. E. Bennett, L. L. Case, A. H. Guenther, B. E. Newnam, and M. J. Soileau, eds., Laser-Induced Damage in Optical Materials: 1992, Proc. SPIE 1848 (1993).

H. E. Bennett, L. L. Case, A. H. Guenther, B. E. Newnam, and M. J. Soileau, eds., Laser-Induced Damage in Optical Materials: 1993, Proc. SPIE 2114 (1994).

H. E. Bennett, A. H. Guenther, M. R. Kozlowski, B. E. Newnam, and M. J. Soileau, eds., Laser-Induced Damage in Optical Materials: 1994, Proc. SPIE 2428 (1995).

H. E. Bennett, A. H. Guenther, M. R. Kozlowski, B. E. Newnam, and M. J. Soileau, eds., Laser-Induced Damage in Optical Materials: 1995, Proc. SPIE 2714 (1996).

H. E. Bennett, A. H. Guenther, M. R. Kozlowski, B. E. Newnam, and M. J. Soileau, eds., Laser-Induced Damage in Optical Materials: 1996, Proc. SPIE 2966 (1997).

G. J. Exarhos, A. H. Guenther, M. R. Kozlowski, and M. J. Soileau, eds., Laser-Induced Damage in Optical Materials: 1997, Proc. SPIE 3244 (1998).

G. J. Exarhos, A. H. Guenther, M. R. Kozlowski, K. Lewis, and M. J. Soileau, eds., Laser-Induced Damage in Optical Materials: 1998, Proc. SPIE 3578 (1999).

G. J. Exarhos, A. H. Guenther, M. R. Kozlowski, K. Lewis, and M. J. Soileau, eds., Laser-Induced Damage in Optical Materials: 1999, Proc. SPIE 3902 (2000).

G. J. Exarhos, A. H. Guenther, M. R. Kozlowski, K. Lewis, and M. J. Soileau, eds., Laser-Induced Damage in Optical Materials: 2000, Proc. SPIE 4347 (2001).

G. J. Exarhos, A. H. Guenther, K. Lewis, M. J. Soileau, and C. J. Stolz eds., Laser-Induced Damage in Optical Materials: 2001, Proc. SPIE 4679 (2002).

G. J. Exarhos, A. H. Guenther, K. Lewis, N. Kaiser, M. J. Soileau, and C. J. Stolz eds., Laser-Induced Damage in Optical Materials: 2002, Proc. SPIE 4932 (2003).

G. J. Exarhos, A. H. Guenther, K. Lewis, N. Kaiser, M. J. Soileau, and C. J. Stolz eds., Laser-Induced Damage in Optical Materials: 2003, Proc. SPIE 5273 (2004).

G. J. Exarhos, A. H. Guenther, K. Lewis, N. Kaiser, M. J. Soileau, and C. J. Stolz eds., Laser-Induced Damage in Optical Materials: 2004, Proc. SPIE 5647 (2005).

G. J. Exarhos, A. H. Guenther, K. Lewis, D. Ristau, M. J. Soileau, and C. J. Stolz eds., Laser-Induced Damage in Optical Materials: 2005, Proc. SPIE 5991 (2006). 
G. J. Exarhos, A. H. Guenther, K. Lewis, D. Ristau, M. J. Soileau, and C. J. Stolz eds., Laser-Induced Damage in Optical Materials: 2006, Proc. SPIE 6403 (2007).

G. J. Exarhos, D. Ristau, M. J. Soileau, and C. J. Stolz eds., Laser-Induced Damage in Optical Materials: 2007, Proc. SPIE 6720 (2008).

G. J. Exarhos, D. Ristau, M. J. Soileau, and C. J. Stolz eds., Laser-Induced Damage in Optical Materials: 2008, Proc. SPIE 7132 (2008).

\section{Compact Discs:}

A. H. Guenther, ed., Laser-Induced Damage in Optical Materials: Collected papers 1969-1998 (a three CD-ROM set available from SPIE, P.O. Box 10, Bellingham, WA 98227-0010) (1999).

A. H. Guenther, ed., Laser-Induced Damage in Optical Materials: Collected papers 1999-2003 (CD-ROM available from SPIE, P.O. Box 10, Bellingham, WA 98227-0010) (2004).

Laser-Induced Damage in Optical Materials: 40th Anniversary Collected Papers on DVD, 1969-2008 (Special Collection) Proceedings of SPIE Volume: CDP50

\section{Journal articles:}

A. J. Glass and A. H. Guenther, eds., Laser-Induced Damage in Optical Materials: A conference Report, Appl. Opt. 13 (1): 74-88 (1974).

A. J. Glass and A. H. Guenther, eds., Laser-Induced Damage in Optical Materials: $6^{\text {th }}$ ASTM Symposium, Appl. Opt. 14 (3): 698-715 (1975).

A. J. Glass and A. H. Guenther, eds., Laser-Induced Damage in Optical Materials: $7^{\text {th }}$ ASTM Symposium, Appl. Opt. 15 (6): 1510-1529 (1976).

A. J. Glass and A. H. Guenther, eds., Laser-Induced Damage in Optical Materials: 8th $^{\text {th }}$ ASTM Symposium, Appl. Opt. 16 (5): 1214-1231 (1977).

A. J. Glass and A. H. Guenther, eds., Laser-Induced Damage in Optical Materials: 9th ASTM Symposium, Appl. Opt. 17 (6): 2386-2411 (1978).

A. J. Glass and A. H. Guenther, eds., Laser-Induced Damage in Optical Materials: 10 th ASTM Symposium, Appl. Opt. 18 (13): 2212-2229 (1979).

H. E. Bennett, A. J. Glass, A. H. Guenther, and B. E. Newnam, eds., Laser-Induced Damage in Optical Materials: 11th ASTM Symposium, Appl. Opt. 19 (14): 2375-2397 (1980).

H. E. Bennett, A. J. Glass, A. H. Guenther, and B. E. Newnam, eds., Laser-Induced Damage in Optical Materials: $12^{t h}$ ASTM Symposium, Appl. Opt. 20 (17): 3003-3019 (1981).

H. E. Bennett, A. H. Guenther, D. Milam, and B. E. Newnam, eds., Laser-Induced Damage in Optical Materials: $13^{\text {th }}$ ASTM Symposium, Appl. Opt. 22 (20): 3276-3296 (1983).

H. E. Bennett, A. H. Guenther, D. Milam, and B. E. Newnam, eds., Laser-Induced Damage in Optical Materials: $14^{\text {th }}$ ASTM Symposium, Appl. Opt. 23 (21): 3782-3795 (1984).

H. E. Bennett, A. H. Guenther, D. Milam, and B. E. Newnam, eds., Laser-Induced Damage in Optical Materials: $15^{\text {th }}$ ASTM Symposium, Appl. Opt. 25 (2): 258-275 (1986).

H. E. Bennett, A. H. Guenther, D. Milam, and B. E. Newnam, eds., Laser-Induced Damage in Optical Materials: $16^{\text {th }}$ ASTM Symposium, Appl. Opt. 26 (5): 813-827 (1987).

A. H. Guenther, "Optics damage constrains laser design and performance," Laser Focus World, 29, 83-87, 1992.

A. H. Guenther, "Previewing the Boulder Damage Symposium," Lasers and Optronics 12, 25-26,1993.

A. H. Guenther, "Laser-Induced Damage in Optical Materials at the October 6-8, 1997 Symposium on Optical Materials for High-Power Lasers (Boulder Damage Symposium), Boulder, Colorado" J. Laser Appl. 9, 261$266,1997$. 
Downloaded From: https://www.spiedigitallibrary.org/conference-proceedings-of-spie on 26 Apr 2023

Terms of Use: https://www.spiedigitallibrary.org/terms-of-use 